\title{
The Effects of Market Competition, Capital Structure, and CEO Duality on Firm Performance: A Mediation Analysis by Incorporating the GMM Model Technique
}

\author{
Riaqa Mubeen ${ }^{1, *}$, Dongping Han ${ }^{1}$, Jaffar Abbas ${ }^{2, *} \mathbb{C}$ and Iftikhar Hussain ${ }^{3}(\mathbb{C}$ \\ 1 School of Management, Harbin Institute of Technology (HIT), No. 92 West Dazhi Street, Nangang District, \\ Heilongjiang, Harbin 150001, China; handongping@hit.edu.cn \\ 2 Antai College of Economics and Management (ACEM), School of Media and Communication (SMC), \\ Shanghai Jiao Tong University (SJTU), No. 800 Dongchuan Road Minhang District, Shanghai 200240, China \\ 3 Dean: Faculty of Computing and Engineering, University of Kotli Azad Jammu and Kashmir (UOKAJK), \\ Kotli 111000, Pakistan; iftikhar_raja@live.com \\ * Correspondence: riaqamubeen@gmail.com (R.M.); abbas512@sjtu.edu.cn (J.A.)
}

Received: 16 March 2020; Accepted: 21 April 2020; Published: 24 April 2020

check for updates

\begin{abstract}
This current study is one of the few investigations to conduct a focalized examination of the relationship between CEO duality and firm performance; however, this relationship seems to be imprecise due to the impact of the invention mechanism. This study explores the effect of CEO duality to achieve firm performance through the mediating effects of capital structure and market competition, which is an innovative model. The study incorporated the generalized method of moments (GMM) model to examine the proposed association of the CEO duality and firm performance, and the findings specified a negative relationship between CEO duality and firm performance. The results indicated that capital structure partially mediated the association between CEO duality and firm performance. The results also showed that market competition fully mediated this linkage between CEO duality and firm performance, which in turn specified a significant positive relationship with market competition, which mediated a positive relationship. By incorporating these mediators, the results determined that CEO duality reduces firm performance through the capital structure; however, it enhances firm performance by stimulating market competition.
\end{abstract}

Keywords: firm performance; company profitability; market competition; CEO duality; capital structure; GMM model

\section{Introduction}

CEO duality is a phenomenon where the chief executive officer of a company occupies the chair of the company's board of directors, along with his/her regular management position [1]. Recognition of the effect of CEO duality on firm performance has attracted much attention from research scholars [2,3]. Previous research investigating the impact of CEO duality on enhanced firm performance provided mixed results. The outcomes of the current literature are inconclusive, ranging from positive to negative, and sometimes indicating an insignificant relationship between CEO duality and firm performance [4-7]. Scholars arguing a negative association between CEO duality and firm performance support their findings based on agency theory. According to this theory, a CEO with a dual role does not work for shareholders' interest; instead, the CEO decides to maximize his/her personal benefits, which ultimately leads to agency problems [8], thereby resulting in an adverse performance of the firm $[9,10]$. On the other hand, researchers supporting the positive impact of CEO duality on firm 
performance refer to stewardship theory to support their stance. Stewardship theory assumes that the dual role of a CEO endorses a more concentrated and flexible governance structure, which enhances the managerial efficiency in dynamic business surroundings [11,12], thereby leading to high firm performance. In the face of these controversial findings, it is crucial to conduct an in-depth analysis by considering additional factors that underlie the relationship between CEO duality and firm performance. Subsequent studies have advocated that the intervening or mediating variables among the CEO duality and firm performance relationship must be investigated to reveal how CEO duality influences a firm's performance [6,13]. However, studies have primarily not investigated the mediating factors to explain this effect [14]. This study proposes capital structure and market competition as the two parallel mediating mechanisms to explain how CEO duality influences firm performance, and thus attempts to fill this gap in the literature.

We emphasize capital structure and market competition as mediating variables in this research because earlier studies demonstrated that these two factors are significant predictors of firm performance. The literature related to capital structure theorized and empirically found that capital structure determines the provision of external funds to a firm to create growth opportunities and to improve firm performance [15]. We investigate capital structure as a mediating force to discuss the effect of CEO duality on maintainable firm performance at a greater depth [16]. Market competition refers to a valuable resource that allows firms to produce quality products to compete in an industry for the sake of higher profits [17]. This study sheds light on the direct impact of CEO duality on market competition, as previous literature recommended that product market competition should not be neglected in corporate governance literature $[18,19]$. According to the authors' knowledge, there is no study available that investigates the mediating role of market competition on the association of CEO duality with firm performance. Thus, this is the first paper to highlight the impact of market competition on the CEO duality and admissible firm performance association. In the following sections, we present our opinions on why CEO duality should affect both mediators, namely, capital structure and market competition, and, ultimately, firm performance.

By investigating the two mediating factors, the present study enhances our understanding of the effect of CEO duality on firm performance. Theoretically, this paper contributes to the corporate governance studies on how the $\mathrm{CEO}$ duality and firm performance association operates. According to the existing literature, studies investigating the CEO duality and justifiable firm performance relationship have produced mixed findings and have led to calls for future research in order to achieve a better understanding of this relationship. In this regard, to respond to this call, it is vital to fill the research gap by probing the mediating variables in the relationship between CEO duality and firm performance $[16,20]$. We consider market competition and capital structure as mediators for this study, as recommended by previous studies $[18,21]$. The reason for considering capital structure as a mediating mechanism in this study is that previous research suggested that it should be examined in the context of a developing country, where governance structure is better [16]. To respond to this call, we investigate this study in the context of China, which is the world's largest developing country and which could be the best example of a reliable governance mechanism to examine this relationship. Moreover, this study also enhances our understanding of CEO duality at the highest leadership ranks in an organization and contributes to the corporate governance literature.

There are several reasons to select China for this study; first, China has the largest emerging market and the second-largest economy in the world, which displays different environments, more so than developed countries. Second, the organizational structure in developing countries is different from that in developed countries due to inefficient financial markets, heavy government involvement, and weak legal institutions [22]. Due to different corporate governance mechanisms in developing countries, the efficiency of CEO duality in firm performance may change. Third, existing studies suggest examining the $\mathrm{CEO}$ duality and firm performance relationship in the context of a developing country, where corporate governance is good [16]; thus, among developing economies, China represents the largest economy with a good and developed governance structure, and it also provides a very exciting 
setting to refine and test previous organizational theories [23]. For instance, market participants and the government developed the corporate governance structure of Chinese firms. As a further example, in 2006, the China Securities Regulatory Commission (CSRC) focused on the improvement of governance structure as a priority [24]. In response to deepening market development, Chinese firms have gradually implemented corporate governance structures; in particular, many measures were adopted in the area of the board of directors and executives [25]. All of these efforts have supported the improvement of the governance structure of Chinese firms and have facilitated corporate governance reforms. Similarly, we have noticed a significant increase in the dual role of CEOs in China. Fourth, in addition to the improvement of the governance structure of Chinese firms, China has also helped to shed light on other developing countries [26]. However, the CEO duality and firm performance relationship remains fairly limited in emerging countries; therefore, due to the large economy and the greatest work on corporate governance structure, China is a very interesting economy for this study. Figure 1 below shows the theoretical gramework.

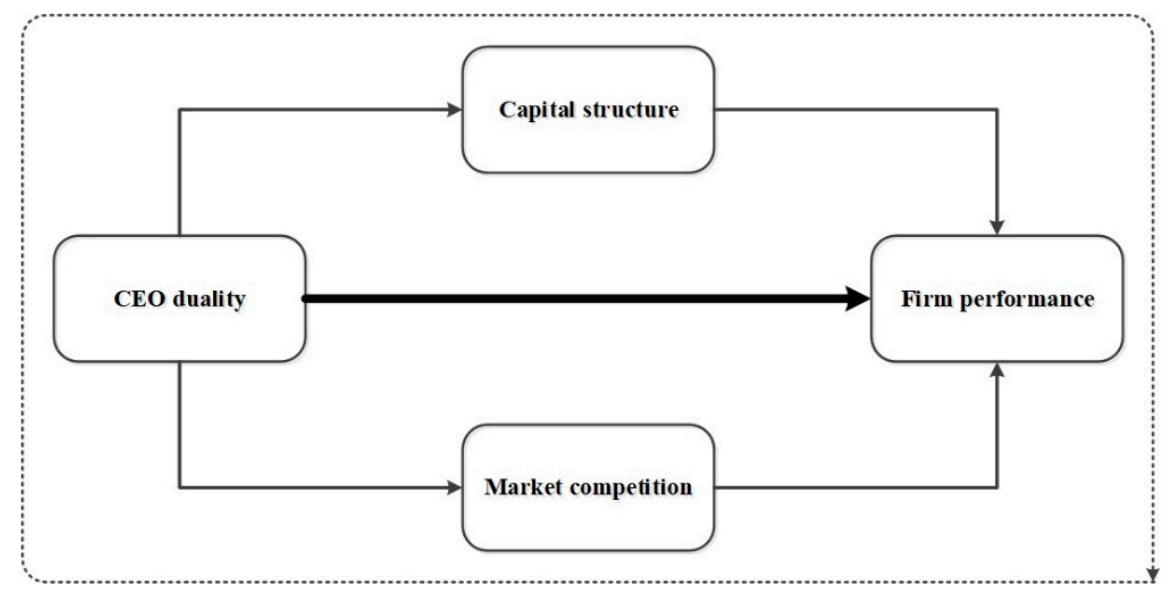

Figure 1. Conceptual framework of the study. Note. The study theoretical framework specifies the link between the chosen variacles.

The objective of this study is to examine the link between CEO duality and firm performance by considering the mediating effects of capital structure and market competition in a Chinese context. Capital structure and market structure affect CEO decisions regarding processes and motivate CEOs to perform well in order to compete in market competition and to influence firm profit. We used the generalized method of moment (GMM) model to examine the relationship between CEO duality and firm performance, and the outcomes of this study indicate that CEO duality has a negative association with firm performance and that capital structure negatively mediates this relationship. Furthermore, market competition positively mediates the CEO duality and firm performance relationship; market competition encourages shareholders and investors to invest in competitive markets.

The organization of the remainder of the study is as follows. The first section describes the relevant literature and development of the hypotheses. The second section refers to the empirical analysis of the proposed hypotheses. The third section of the study is the discussion, while the last component presents the conclusions and future directions of the study. Figure 1 outlines the conceptual framework of this study.

\section{Literature Review and Hypotheses}

\subsection{CEO Duality and Firm Performance}

As noted in the existing literature, the relationship between firm performance and the CEO dual structure is well-rooted in agency and stewardship theories. Supporters of the agency theory have debated whether a CEO with a dual role acts efficiently in his/her private interests and whether the 
CEO might pursue profits that depart from the investors' benefits $[9,10]$. Thus, this naturally leads to agency problems between shareholders and executives and highlights the adverse impact of the CEO duality and firm performance association [13]. For instance, a CEO with dual powers might decide to maximize his/her interests at the expense of shareholders. The dual role mainly decreases board powers and limits board independence to achieve its authority role and also endorses CEO entrenchment $[6,27]$. At times, CEOs with dual control hire board members that may be less active in monitoring board activities, thus leading to poor firm performance [28]. Additionally, in a weak and political organizational structure, the CEO might misuse his/her dual power and appoint a closely linked person as a director who is likely to perform according to the CEO's direction [29]. This advocates that CEO duality encounters the board's capability/abilities to work as a monitor. Thus, this decreases the efficiency of organizational operations, such as monitoring activities performed by selected boards, and consequently results in the waste of resources [7]. As such, agency theory emphasizes the separate roles of the CEO and the chairman of directors [30]. All of these arguments suggest that CEO duality weakens the organization monitoring structure and negatively influences firm performance [31]. Additionally, the empirical work on the CEO duality and firm performance relationship is mostly conflicting and unconvincing. Some studies even failed to produce any significant relationship between CEO duality and firm performance [32,33]. From an agency theory perspective, extant research found a negative impact of the CEO duality and firm performance relationship due to reasons such as CEO private benefits and CEO replacement cost or extra cost relevant to the CEO $[34,35]$. Furthermore, a CEO with a dual role does not work in the best interests of shareholders, which naturally leads to agency problems. It is also debated that CEOs with more power are overconfident about the results of their decisions and make financial decisions without the consent of specialized experts. At times, these decisions become costly due to judgmental errors, and it becomes challenging to achieve the desired performance of a firm [36,37]. In particular, several studies have observed the negative impact of CEO duality on firm performance, measured with different performance measurements such as shareholder return, return on equity, Tobin's $Q$, return on investment, and return on assets $[14,20,38,39]$.

In contrast, the stewardship theory posits that "the top executives want to be a good steward of the corporate assets" [40]. Senior leaders try to increase firms' values once they hold dual positions in a firm and try to reduce agency costs [41]. For instance, the dual structure reduces the agency costs among the $\mathrm{CEO}$ and the board; thus, it can increase firm performance [42]. Furthermore, the stewardship theory advocates that the CEO, obtaining full power, promotes the communication level with the board and might lead to higher firm performance [43,44]. In particular, CEOs with more power will play an active role in implementing the firm strategy due to the clear line of authority among executives [11]. Thus, a single leadership structure may help to avoid the confusion commonly found among many executive positions [45]. From the corporate leadership perspective, unique leadership can improve organizational proficiency and shareholders' worth due to the CEO's knowledge about the firm's strategic policies and challenges $[6,46,47]$. For instance, CEOs focus on business activities, and the chairman runs the board decision process. Therefore, by merging these positions, an experienced CEO can also be a sounding board chair and a valuable asset for business [48]. For example, many studies propose that assigning the $\mathrm{CEO}$ and chairman role to a single person empowers firms to respond quickly to market situations and thus may result in more efficient execution of strategic decision processes $[40,43]$. Thus, arguments constructed on this theory recommend a positive effect of the CEO duality and firm performance association. The dual role of the CEO promotes managerial efficiency, enhances the communication level, and offers a flexible leadership structure by protecting his/her interests through the linking of management structure in an organization [43]. CEO duality highlights the benefits of active stewardship due to a CEO's knowledge about the firm's strategic policies and challenges [46]. Many studies have discussed the positive relationship of CEO duality and firm performance with different viable firm performance measurements such as ROA, ROE, sales growth, and Tobin's Q $[7,13,49,50]$. Some studies have not provided a significant impact of CEO duality on firm performance $[6,51]$. Therefore, after summarizing all of these arguments, no survey provided 
conclusive results as to whether CEO duality positively affects firm performance due to persuasive leadership authority or whether it negatively affects it due to the CEO's values. Therefore, all of these studies suggest that the effect of CEO duality on firm performance is still questionable, and it needs to be further examined. Based on all of these studies, we hypothesize the following:

H1: CEO duality has significant and adverse effects on firm performance.

\subsection{The Relationship between CEO Duality and Firm Performance with the Mediating Effect of Capital Structure}

Research suggests that the executive's values and objectives influence a firm's strategic decisions regarding its capital structure [52]. The agency theory assumes that top management supports those decisions which satisfy a CEO's self-interest [9]. Managers may increase leverage, which reduces the equity base to consolidate their voting power [53]. The agency theory also states that executives can protect their benefits by joining a joint leadership structure in an organization [40]. CEO duality provides internal satisfaction for the CEO in terms of achievement, intrinsic motivation, respect, and recognition at the top position. This motivates the CEO to adopt more leverage and to work in the shareholders' best interests. For instance, [54] reported a significant relationship between CEO duality and leverage by arguing that the dual role of a CEO adopts more leverages to gain more advantages. Another study reported a positive connection between CEO duality and debt [55]. In contrast, another researcher argued that CEOs with dual roles should prefer to use more leverage over the owner's equity and suggested a positive association between CEO duality and firm debt [56].

Where a firm proliferates, there is a trend of high debt to equity ratios [15]. Therefore, capital structure is essential for firm growth in order to achieve strategic objectives and to maximize profit. Capital structure and firm performance have attracted much debate, and empirical findings provide mixed results. Studies on capital structure posit that while determining the leverage level, agency conflicts occur between shareholders and managers, which negatively influences firm performance [9]. For instance, advocates of the agency theory suggest that the capital structure of a firm negatively impacts financial performance $[57,58]$. Capital structure is an essential mediating variable in understanding how the dual role of a CEO is related to firm performance, and it is useful to examine the CEO duality and firm performance association. Existing studies demonstrate the negative effect of capital structure on firm performance [58]. Capital structure is an external funding source that allows a firm to gain more products, and research suggests that an executive's values and objectives influence a firm's strategic decisions regarding its capital structure and thus negatively impact firm performance [52]. Other studies have also found the same results regarding executives and their preference to adopt high debt, which increases shareholders' benefits and ultimately negatively impacts firm performance [16]. Based on all of these studies, we hypothesize the following:

H2: Capital structure mediates the link between CEO duality and firm performance.

H2a: $C E O$ duality is positively linked to firm leverage.

H2b: Capital structure negatively mediates the association between CEO duality and firm performance.

\subsection{The Relationship between CEO Duality and Firm Performance with the Mediating Effect of Market Competition}

Corporate competitive strategies determine those corporate strategies that are used to gain a competitive advantage [59], expand market share [60], and increase firm performance [17]. Because market competition is vital to achieving firm goals, scholars have increasingly studied the link between competitive strategies and governance [61-63]; for instance, governance structure influences market competition by aligning increments (bonus) for executives [33,64]. There is also reason to believe that the executive's teams should affect market competition. For instance, when an 
executive makes the firm's strategic decisions, he/she is influenced by his/her creative ideas to stay in business for a long time $[65,66]$. Support for the notion that CEO duality should be related to market competition that provides the support of stewardship theory [42], which suggests that decision-making processes can impact market competition in industries. Experimental studies on decision-making have shown that a CEO with a dual role as the chairman of the board of directors makes better and faster decisions as compared to CEOs in a single role in a competitive market [11]. When firms have a good governance structure, they are better able to compete in a market $[43,44]$. Having a dual structure enables executives to overcome decision biases and to improve the decision-making process, including decisions related to a market $[9,47]$.

Market competition is an essential factor that may affect a firm's operating efficiency, financial decisions, and financial performance [17,61,62]. Earlier studies have suggested that competition may affect conservative reporting decisions because of strategic considerations and agency conflict [67]. Experimental research has shown both negative and positive effects on firm performance. Empirical studies argue that product market competition leads to better performance because it serves as a powerful force to solve agency conflicts between owners and managers, which leads to improved firm profitability $[68,69]$. When referring to some studies conducted in emerging markets, we note that their results are in favor of a positive relationship between product market competition and performance $[68,70,71]$. Market competition is an organizational strategy that allows a firm to gain competitive advantages and to improve firm performance [60]. Indeed, previous research has empirically found that market competition is positively related to improved firm performance $[68,72,73]$. Market competition is an organizational strategy that allows a firm to gain competitive advantages and to improve viable performance [60]. Previous research has empirically found that market competition is positively related to durable firm performance [73-75]. Therefore, we hypothesize that market competition is an important mediator to understand how CEO duality improves lasting firm performance [13] because mediation plays a vital role in organizational sciences, and it also discloses how and why one variable affects another [76]. Therefore, we propose the following hypothesis:

H3: Market competition mediates the relationship between CEO duality and firm performance.

H3a: CEO duality is positively associated with market competition.

H3b: Market competition positively mediates the relationship between CEO duality and firm performance.

\section{Research Methods}

\subsection{Sample and Data Collection}

The primary source of data was the China Stock Market and Accounting Research (CSMAR) database, consisting of A-share listed firms. Due to the lack of CEO duality and missing data, we started our sample from 2012 and selected data up until 2017. The reasons why we selected the Chinese economy were because of the great success of this economy among developing countries and the specific work that has been done on the corporate governance role. First, we excluded firms with missing values and then also excluded all firms with missing CEO information. Finally, we retained a sample of 417 firms, covering a six-year study period, with a total of 2502 observations.

\subsection{Variable Measurements}

\subsubsection{Dependent Variable Measurement}

As there is no distinctive measurement that exists for firm performance, we used two alternative performance measurements as the dependent variable. Different performance measurements were 
used to measure firm values, and some variables are used to measure firm performance from different perspectives, e.g., assets, shareholders' equity, and overall profits/net profits after all expenses. For this study, we used performance measurements called ROA (return on assets) and ROE (return on equity), which measure earnings before interest and taxes (EBIT) over assets and operating profit divided by shareholders' equity, respectively, following $[13,20,77]$. ROA emphasizes shareholders' wealth by using the efficiency of firm assets, whereas, the ROE is mostly used in the corporate governance literature and relates to the operating performance of a firm.

\subsubsection{Independent and Control Variables}

In this study, to explore the CEO duality impact on firm performance, we used CEO duality as our primary leading independent variable, also referred to as the leadership structure of the firm. CEO duality was measured by using dummy values; if the CEO also worked as the chairman of the board of directors, 1 was assigned; otherwise, 0 was given, following [78-80]. Additionally, we excluded all firms' observations that changed their organizational leadership structure. We used growth opportunities, firm size, and asset tangibility as control variables. Growth opportunity was measured as changes in the sales revenue of firms. Asset tangibility was measured as the ratio of plant, equipment, and property to the total revenue of the firm [81]. Another control measurement, called firm size, is the most important variable and has been used in almost all corporate finance-related studies. We measured firm size as the log of the sales of the firm [82-84].

\subsubsection{Mediating Variables}

In this paper, we used capital structure and market competition as mediating variables to investigate their mediating role in the association between CEO duality and firm performance. For the mediation variables, we measured capital structure as a debt-to-equity ratio, consistent with [85]. Previous studies have used different measurement techniques to measure market competition, such as [86], including the application of the Herfindahl-Hirschman index (HHI) and the Boone indicator to measure market competition. Previous studies $[73,87]$ have stated that HHI is the best measurement of market competition among the other available measurements. Also, [17,87] reported that firms compete normally based on company sales in the marketplace, which shows the industry competition concerning their profits. Furthermore, many researchers have used the HHI to calculate industry competition firm-level data $[88,89]$. Following $[17,73]$, we measured market competition by applying the sum of the squared market shares of each firm in the industry based on the total sales of that industry. We assigned dummy values to the HHI to categorize firms belonging to the low (high) competitive industry.

\subsection{Models}

Based on this study, we established the following mathematical equations, according to Baron and Kenny $[76,90]$. They discussed some steps in establishing the mediation role. First, a significant relationship between the dependent and independent variables is required. Second, a significant relationship is required between the independent and mediating variables. Third, the dependent variable is regressed on both the independent and the mediating variables, and the mediator must affect the performance of the firm.

$$
\begin{aligned}
& F P_{i t}=\alpha_{0}+\alpha_{1} \text { CEOduality } y_{i t}+\sum_{i=1}^{n} \alpha_{n} . \\
& D R_{i t}=\alpha_{0}+\alpha_{1} \text { CEOduality }_{i t}+\sum_{i=1}^{n} \alpha_{n}
\end{aligned}
$$




$$
\begin{gathered}
F P_{i t}=\alpha_{0}+\alpha_{1} \text { CEOduality }_{i t}+\alpha_{2} D R_{i t}+\sum_{i=1}^{n} \alpha_{n} . \\
H H I_{i t}=\alpha_{0}+\alpha_{1} \text { CEOduality } y_{i t}+\sum_{i=1}^{n} \alpha_{n} \\
F P_{i t}=\alpha_{0}+\alpha_{1} \text { CEOduality } y_{i t}+\alpha_{2} H_{H I}+\sum_{i=1}^{n} \alpha_{n}
\end{gathered}
$$

Equation (1) shows the direct relationship of CEO duality and firm performance; here, FP shows firm performance with two measurements, namely, ROE and ROA. Equation (2) shows the mediating effects of capital structure on this association. Equation (3) was developed for the mediating role of market competition in CEO duality and firm performance.

\subsection{Empirical Approach}

To examine the relationship between CEO duality and firm performance, we used a panel dataset. An endogeneity problem commonly occurs in panel data, which leads to biased and unreliable results [91]. According to the econometric rule, if only one variable exists in the whole model with endogenous issues, then there is a need to use appropriate techniques to deal with the endogeneity [73]. As per the existing CEO literature, we used GMM (generalized method of moments) to investigate the relationship between CEO duality and firm performance [50]. We used the GMM model for various reasons. The leading independent variable of this study, CEO duality, suggests potential endogeneity issues [7]. For example, the appointment of the CEO and the CEO chair may by driven by firm characteristics that affect firms' decision-making processes and thus impact firm performance [13,92-94]. Some other studies have also suggested that a single leadership structure of firms is mostly endogenous; CEO and CEO chairs also have a relationship with some unobserved firm characteristics [94] that leads to endogenous issues.

In a regression model, a variable faces endogeneity problems when there is a correlation among error terms. Also, these problems can arise as an outcome of auto-regression with omitted variables, measurement errors, and auto-correlated errors when CEO duality decision is correlated with the error term due to latent factors [95]. Consequently, it is essential to control endogeneity issues in CEO duality analysis. Therefore, to tackle this endogeneity problem, many econometrics methods have been applied to solve endogeneity issues such as instrumental, lagged dependent variables, random effects, control variables, fixed effects, and the GMM model [96]. Among all models, GMM is the best model with the highest power to deal with endogeneity. Consequently, our preferred estimator for this study was the GMM model proposed by [97]. Within a firm, GMM allows for heteroscedasticity and autocorrelation, and its consistency depends on instrumental validity and the absence of higher-order serial correlation in the error terms.

Before applying the GMM model, we used some tests to check the data to determine whether they were suitable for analysis. We applied a variance inflation factor (VIF) test to check the multicollinearity among data, and we confirmed that there were no multicollinearity problems. Then, we used the Wald test to check the heteroscedasticity of the data, and the results showed that there was no heteroscedasticity in our study. To assess the instrument validity, we used the Sargan test for over-identifying restrictions. The results showed that the instrumental variables were valid and that the over-identifying limits would not be rejected. We tested the data for serial autocorrelation by using the AR (1) and AR (2) tests and found that there was no serial autocorrelation. We checked the data for endogeneity issues and found such problems in our data. To solve the endogeneity issues between error terms and variables, we used the GMM model, consistent with [50]. The results of all of the tests for the instruments showed that our specifications did not suffer from weak instruments and that the instrumental variables performed adequately. 


\section{Results}

Table 1 represents the summary statistics of the entire dependent and independent variables in this study. It stipulates statistics of all of the dependent and independent variables in this study. Panel A describes the descriptive statistics, and Panel B shows the variance inflation factor (VIF). In Panel A, the average ROE value is 0.0273 , with a standard deviation value of 0.172 , and the ROA value is 0.239 , with a standard deviation of 0.523 . CEO duality and market competition have average values of 0.176 and 0.805 , respectively, and the average value of the capital structure is 0.069 , with a standard deviation of 0.089 . The firm growth has an average value of 15.16 . The firm size has a mean value of 9.45 , with a standard deviation of 0.732 , and the asset tangibility has an average value of 1.35 , with a standard deviation of 3.73. Table 1 specifies the descriptive statistics analysis.

Table 1. Descriptive statistics.

\begin{tabular}{cccccc}
\hline \multicolumn{1}{c}{ Panel A Descriptive Statistics } & \multicolumn{2}{c}{ Panel B VIF } \\
\hline VARIABLES & OBS. & MEAN & STD. DEV & VIF & 1/VIF \\
\hline ROE & 2502 & 0.0273 & 0.172 & & 0.424 \\
\hline ROA & 2502 & 0.239 & 0.523 & 1.03 & 6.96 \\
\hline CEO Duality & 2502 & 0.176 & 0.381 & 1.01 & 0.989 \\
\hline $\begin{array}{c}\text { Market } \\
\text { Competition }\end{array}$ & 2502 & 0.805 & 0.396 & 1.00 & 0.998 \\
\hline Capital Structure & 2502 & 0.069 & 0.089 & 1.03 & 0.973 \\
\hline Growth & 2502 & 15.16 & 531.6 & 1.00 & 0.998 \\
\hline Firm Size & 2502 & 9.45 & 0.732 & 1.44 & 0.967 \\
\hline Asset Tangibility & 2502 & 1.35 & 3.73 & 1.37 & 0.729 \\
\hline & & & & VIF Mean & 1.13 \\
\hline
\end{tabular}

In panel $\mathrm{B}$, the VIF is used to check for the absence of multicollinearity. VIF values higher than 10 indicate that some variables suffer from multicollinearity, and VIF values lower than 10 confirm that the data are free from multicollinearity [81,98]. All of the variables in this study show an average VIF value of 1.13 , indicating that the data are free from multicollinearity.

\subsection{Empirical Analysis}

In order to test the CEO duality relationship with firm performance, we employed the GMM model. To test our mediation hypothesis, we used the procedure outlined in [76], in which the authors discussed some steps in establishing a mediation role. First, a significant relationship between the dependent and independent variables is required. For the dependent and independent variable associations, we developed two models with performance measurements, namely, ROE and ROA, respectively. Second, a significant relationship is required between the independent and mediating variables, and for this association, we developed Model 3 and Model 6. Model 3 describes the CEO duality and capital structure association, while Model 6 describes the CEO duality and market competition relationship. Third, the dependent variable is regressed on both the independent and the mediating variable, and the mediator must affect the dependent performance of the firm.

\subsection{Analysis of Hypothesis 1}

Table 2 displays the regression results. We developed two models for Hypothesis 1 to examine the relationship between CEO duality and firm performance. In Models 1 and 2, we measured the CEO duality and performance association with the two performance measurements-returns on equity and return on assets. In Table 2, Model 1 shows that the CEO duality impact is negative on firm performance, 
at a significance level of $1 \%$ and with a coefficient value of -0.074 . Model 2 also shows a negative coefficient value of CEO duality $(-0.014)$ for firm performance. This result shows that CEO duality and firm performance have a negative relationship with both performance measurements, ROE and ROA. Both performance measurements indicated a negative and significant relationship between CEO duality and firm performance; therefore, Hypothesis 1 is accepted according to the results, in which it was suggested that CEO duality negatively affects performance. The agency theory supported our results, as it supplied evidence for this negative relationship. The negative value of CEO duality shows a negative relationship with firm performance, similar to the findings in [14]. Furthermore, a CEO duality structure decreases a firm's performance because it creates agency problems among managers and shareholders [20]. These study results are in accordance with the outcomes of [20], who reported that a CEO with a dual role works for his/her own benefits, which leads to poor firm performance [14]. Table 2 indicates the linkage between CEO duality and firm performance.

Table 2. The relationship between CEO duality and firm performance.

\begin{tabular}{ccc}
\hline & MODEL 1 (ROE) & MODEL 2 (ROA) \\
\hline CEO Duality & $-0.074^{* * * *}$ & $-0.014^{* * *}$ \\
& $(0.037)$ & $(0.007)$ \\
Firm Size & $0.197^{* * *}$ & $0.047^{* * *}$ \\
& $(0.033)$ & $(0.009)$ \\
Asset Tangibility & 7.90 & $-2.63^{* * *}$ \\
& $(7.62)$ & $(1.33)$ \\
Growth & $0.002^{* * *}$ & -5.18 \\
& $(2.89)$ & $(5.66)$ \\
Constant & $-1.61^{* * *}$ & $-0.413^{* * *}$ \\
Wald Test & 0.305 & $(0.089)$ \\
AR (1) & $204.81^{* * *}$ & $77.57^{* * *}$ \\
AR (2) & -2.21 & -1.51 \\
Sargan Test & -2.58 & -1.58 \\
Observation & 4.70 & 0.07 \\
\end{tabular}

Note: Significance levels ${ }^{* * *} p<0.01{ }^{* *} p<0.05$, and ${ }^{*} p<0.1$.

\subsection{Analysis of Hypothesis 2}

Table 3 shows the mediation role of capital structure in the CEO duality and firm performance relationship. In order to test the mediation hypothesis, we first regressed the capital structure on CEO duality for the mediation effect in Model 3, according to [76]. The CEO duality coefficient in Model 3 was highly significant and positive ( $1 \%$ level), which indicates that it impacts positively on firm leverage, supporting the findings of [16,55]. Second, we developed two models (Models 4 and 5) to investigate the capital structure-mediating effect on the relationship between CEO duality and firm performance. In Models 4 and 5, we regressed CEO duality, capital structure, and firm performance together to investigate the mediating role in the CEO duality and firm performance relationship with ROA and ROE. In Model 4, we measured the CEO duality effect on firm performance with the ROE variable, and in Model 5, we measured with the ROA performance measurement. The coefficient of CEO duality in both models was negative and highly significant at $1 \%$ when we regressed capital structure, CEO duality, and firm performance together. The CEO duality coefficient indicates that leverage negatively mediates this relationship, which supports Hypothesis 3, namely, that capital structure negatively mediates the $\mathrm{CEO}$ duality and firm performance relationship, and this result is consistent with [16]. In line with previous findings, we provide support that the mediating effect of debt on the CEO duality and firm performance relationship is negative. Overall, the analysis confirms that capital structure partially mediates the link between CEO duality and firm performance. Table 3 below shows the association between capital structure, CEO duality, and firm performance. 
Table 3. Capital structure, CEO duality, and firm performance.

\begin{tabular}{cccc}
\hline & Model 3 (DR) & Model 4 (ROE) & Model 5 (ROA) \\
\hline CEO Duality & $0.936^{* * *}$ & $-0.546^{* *}$ & $-0.018^{* * *}$ \\
& $(0.307)$ & $(0.322)$ & $(0.065)$ \\
Leverage & & $-1.745^{* * *}$ & $0.174^{* * *}$ \\
& & $(0.368)$ & $(0.065)$ \\
Firm Size & $0.075^{* * *}$ & $1.03^{* * *}$ & $0.158^{* * *}$ \\
& $(0.026)$ & $(0.204)$ & $(0.0511)$ \\
Asset Tangibility & $-7.71^{* * *}$ & $-8.60^{* * *}$ & $-1.49^{* * *}$ \\
& $(3.38)$ & $(3.80)$ & $(0.065)$ \\
Growth & $8.36^{* * *}$ & $-0.0001^{* * *}$ & $-9.14^{*}$ \\
& $(2.02)$ & $(4.05)$ & $(6.43)$ \\
Constant & $-7.97^{* * *}$ & $-9.21^{* * *}$ & $-1.43^{* * *}$ \\
Wald Test & $(2892)$ & $(1.90)$ & $(0.003)$ \\
AR (1) & $59.90^{* * *}$ & $376.29 * * *$ & $82.88^{* * *}$ \\
AR (2) & -2.86 & -3.07 & -1.52 \\
Sargan Test & -1.23 & -2.12 & -1.38 \\
Observation & 13.0 & 9.10 & 0.01 \\
\end{tabular}

Note: Significance levels ${ }^{* * *} p<0.01,{ }^{* *} p<0.05$, and ${ }^{*} p<0.1$. DR, capital structure.

\subsection{Analysis of Hypothesis 3}

Table 4 presents the mediating role of market competition in the CEO duality and firm performance relationship. In Model 6, we regressed market competition on CEO duality, and the CEO duality coefficient was positive and statistically significant at the $1 \%$ level, which indicates that market competition and CEO duality have a positive relationship. These findings are in line with [72]. Table 4 has stipulated link CEO duality, market competition, and firm performance.

Table 4. CEO duality, market competition, and firm performance.

\begin{tabular}{cccc}
\hline & MODEL 6 (HHI) & MODEL 7 (ROE) & MODEL 8 (ROA) \\
\hline CEO Duality & $2.68^{* * * *}$ & $0.159^{* * *}$ & $0.163^{* *}$ \\
& $(1.20)$ & $(0.077)$ & $(0.090)$ \\
Market Competition & & $-0.189^{* * *}$ & $-0.102^{* * *}$ \\
& & $(0.072)$ & $(0.051)$ \\
Firm Size & $-0.566^{* *}$ & $1.30^{* * *}$ & $1.102^{* * *}$ \\
& $(0.302)$ & $(0.363)$ & $(0.373)$ \\
Asset Tangibility & $6.58^{* *}$ & $-5.09^{* * * *}$ & $4.45^{* * *}$ \\
& $(3.93)$ & $(1.67)$ & $(1.71)$ \\
Growth & $0.003^{* * *}$ & $0.0002^{* * *}$ & $0.0002^{* * *}$ \\
& $(0.0005)$ & $(0.0001)$ & $(9.49)$ \\
Constant & $5.60^{* * *}$ & $11.3^{* * * *}$ & $-9.75^{* * *}$ \\
Wald Test & $(2.86)$ & $(3.23)$ & $(3.33)$ \\
AR (1) & $0.626^{* * *}$ & $205.78^{* * *}$ & $78.47^{* * *}$ \\
& -3.23 & 0.66 & -0.16 \\
AR (2) & $(0.001)$ & $(0.506)$ & $(0.869)$ \\
Sargan Test & -0.05 & 0.94 & 1.01 \\
Observation & $(0.962)$ & $(0.345)$ & $(0.314)$ \\
\hline
\end{tabular}

Note: Significance levels ${ }^{* * *} p<0.01,{ }^{* *} p<0.05$, and ${ }^{*} p<0.1$. HHI, Herfindahl-Hirschman index.

To examine the mediating impact of market competition on the relationship between CEO duality and firm performance, we developed two models (Models 7 and 8) with two different performance measurements. In Models 7 and 8, we regressed market competition, CEO duality, and performance (ROE and ROA) together. The coefficient of CEO duality in Models 7 and 8 is positive and significant at the $1.0 \%$ level, which shows that market competition positively mediates the relationship between CEO duality and firm performance. Thus, these results support Hypothesis 3; market competition 
positively mediates this relationship [72] and provides support for our conclusion, also finding that market competition positively mediates the CEO duality and firm performance relationship. Market competition fully mediates the association between CEO duality and firm performance, which predicts that CEO duality will increase firm profits and help to reduce agency conflicts among shareholders and managers, thus impacting positively on firm performance [99]. After summarizing all of these results, Table 5 describes the results of all of the hypotheses in this study. Table 5 reflects hypotheses testing and summary of the study results

Table 5. Results summary.

\begin{tabular}{|c|c|}
\hline Hypotheses & Whether Hypotheses are Supported \\
\hline $\begin{array}{l}\text { H1: There is a direct relationship between CEO duality and firm } \\
\text { performance. }\end{array}$ & Supported \\
\hline $\begin{array}{l}\text { H2: Capital structure mediates the link between CEO duality and } \\
\text { firm performance. } \\
\text { H2a: CEO duality is positively linked to firm leverage. } \\
\text { H2b: Capital structure negatively mediates the association } \\
\text { between CEO duality and firm performance. }\end{array}$ & Supported \\
\hline $\begin{array}{l}\text { H3: Market competition mediates the relationship between CEO } \\
\text { duality and firm performance. } \\
\text { H3a: CEO duality is positively associated with market competition. } \\
\text { H3b: Market competition positively mediates the relationship } \\
\text { between CEO duality and firm performance. }\end{array}$ & Fully supported mediated effect \\
\hline
\end{tabular}

Figure 2a presents the direct relationship between CEO duality and firm performance, and it offers the mediation effect of debt and market competition on this relationship. The graph shows that the immediate CEO duality negatively affects firm performance, with a value of -0.074 . The mediating influence of debt on the CEO duality and firm performance relationship is negative, with a value of -0.546 , but is higher than the direct link between CEO duality and firm performance. This means that CEOs perform worse when variables are regressed together. The mediation effect of market competition on CEO duality and enhanced firm performance is positive, with a value of 0.159 ; hence, market competition fully mediates this relationship. In competitive markets, a CEO with dual powers positively impacts firm performance.

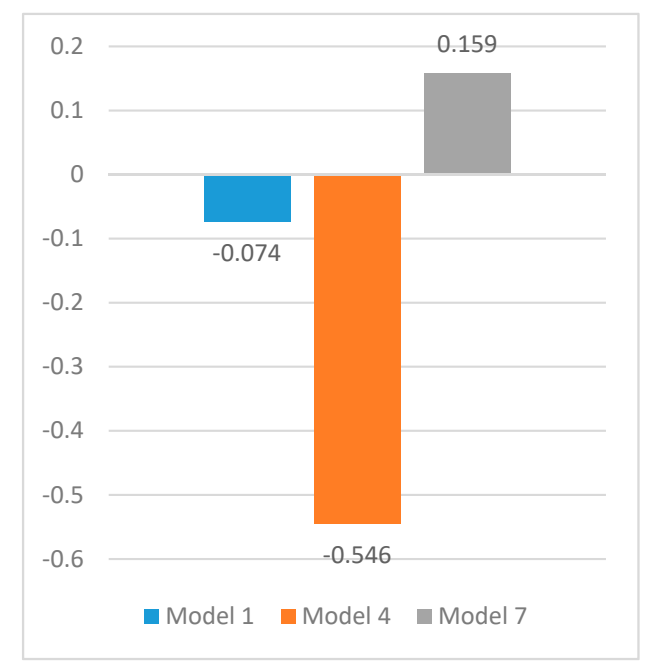

(a) With performance measurement ROE

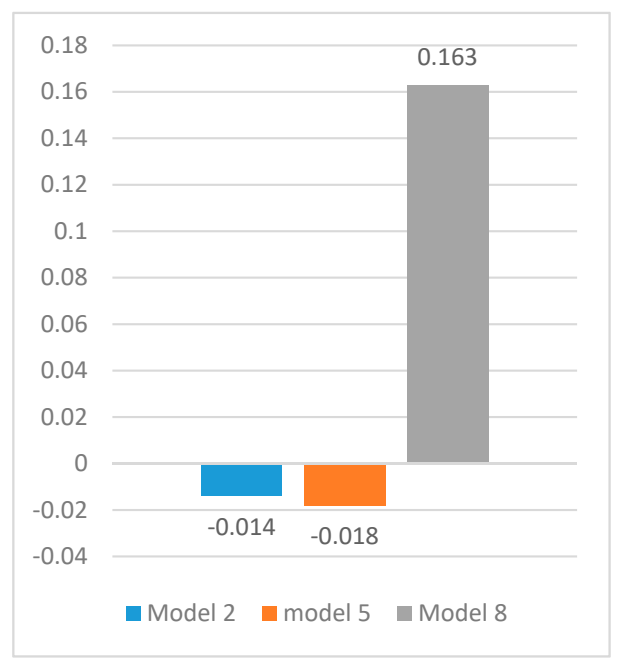

(b) With performance measurement ROA

Figure 2. Mediation effect of capital structure and market competition on the CEO duality and firm performance relationship. 
The relationship in Figure $2 b$ is the same as that in Figure 2a. CEO duality and firm performance have a negative relationship, and capital structure influences this relationship negatively. The mediation effect of market competition (HHI) is positive and entirely changes this relationship. In competitive markets, a CEO with a dual role has a positive impact, with a value of 0.163 , which means that CEOs work positively in high-competition markets, and this affects firm performance, undoubtedly consistent with [99]. Figure 2 shows mediation effects beyween the chosen variables of the study.

\subsection{Robustness Analysis}

To confirm the robustness of our main results that CEO duality is negatively associated with firm performance and that capital structure and market competition mediates this relationship, we performed a robustness test. We used firm performance (ROA 2) as another ROA proxy by dividing net income by total assets, similar to [100]. The coefficient of CEO duality was negative and significant in Model 9, and this negative coefficient of CEO duality indicates that CEOs with a dual role affects negatively on firm performance. In Model 10, capital structure negatively mediates the CEO duality and firm performance relationship. Model 11 indicates a positive coefficient of CEO duality, which suggests that by adding market competition as a mediator, CEOs perform positively and thus enhance performance. Overall, our robustness analysis shows that capital structure and market competition mediate this association, which is consistent with our main findings. Table 6 specifies robustness analysis on the relationships of capital structure and market competition mediate the CEO duality and firm performance.

Table 6. Do capital structure and market competition mediate the CEO duality and firm performance?

\begin{tabular}{clll}
\hline & Model 9 & Model 10 & Model 11 \\
\hline CEO Duality & $-0.0134^{* * *}$ & $-0.015^{* *}$ & $0.1212^{* *}$ \\
& $(0.0073)$ & $(0.0065)$ & $(0.0722)$ \\
Leverage & & $-0.153^{* * *}$ & \\
& & $(0.030)$ & $-0.1126^{* *}$ \\
Market Competition & & & $(0.064)$ \\
& & & $1.046^{* * *}$ \\
Firm Size & $\left(0.0313^{* * *}\right.$ & $0.0399^{* * *}$ & $(0.442)$ \\
Asset Tangibility & $-1.780^{*}$ & $(0.0080)$ & $-4.60^{* * *}$ \\
Growth & $(1.100)$ & $-2.26^{* *}$ & $(2.170)$ \\
Constant & 0.0037 & $(1.33)$ & $-0.00205^{* * *}$ \\
Wald Test & $(0.0005)$ & $8.870^{* *}$ & $(0.054)$ \\
AR (1) & $-0.2683^{* * *}$ & $(4.970)$ & -9.19 \\
AR (2) & $(0.0511)$ & -0.337 & $(3.905)$ \\
Sargan Test & $57.279^{* * *}$ & $(0.0746)^{* * *}$ & $57.280^{* * *}$ \\
Observation & -1.55 & $66.786^{* * *}$ & -0.46 \\
& -1.71 & -1.38 & 1.07 \\
& 548.82 & -1.67 & 280.78 \\
& 2502 & 1363.05 & 2502 \\
\hline
\end{tabular}

Note: Significance levels ${ }^{* * *} p<0.01{ }^{* *} p<0.05$, and ${ }^{*} p<0.1$.

\section{Conclusions and Future Direction}

Many researchers have attempted to investigate the direct association between CEO duality and firm performance. Some of them have reported a positive relationship [7], while others have declared a negative relationship $[6,14,39]$, but all of these findings are imprecise and incomplete. Some studies have highlighted that this relationship might be mediated by some other factors that indirectly influence it and suggested that the mediators should be examined to understand the influence of CEO duality on firm performance $[13,14]$. We addressed this research gap by using two variables (capital structure and market competition) as parallel mediators to explain the relationship between CEO duality and firm performance [101-105]. 
In this study, we analyzed 2502 firms' observations to examine the mediating roles of capital structure and market competition in the relationship between CEO duality and firm performance. The theoretical basis for our study was drawn from the agency and stewardship theories. In this study, it was hypothesized that CEO duality has an impact on capital structure, market competition, and firm performance, and the findings support all of the proposed hypotheses. CEO duality, capital structure, and market competition are associated with firm performance, and capital structure partially mediates the CEO duality and firm performance association [72,106]. All of these results are consistent with previous studies [16]. CEO duality has a positive effect on market competition, and market competition fully mediates the impact of CEO duality on firm performance.

Theoretically, this work deepens our understanding of the relationship between CEO duality and firm performance in several ways. Based on the agency and stewardship theories, this study emphasizes that $\mathrm{CEO}$ duality has an instrumental role in firm performance by employing the executive's powers and managerial skills. Furthermore, empirical support is provided for the positive relationship between CEO duality and capital structure, and it was revealed that capital structure negatively mediates the relationship between CEO duality and firm performance.

Second, we found a direct relationship between CEO duality and market competition, which was not explored previously. We also determined that market competition positively mediates the effect of CEO duality on firm performance. The examination of the mediating role of market competition and capital structure between CEO duality and firm performance is an essential step toward understanding the cost and benefits of a single corporate governance structure for a firm.

This study also has certain limitations that could be addressed by future studies. The current study only covered the mediating role of capital structure and market competition on the CEO duality and firm performance connection. It did not include other essential firm strategies, such as franchising and diversification, in the examination. These elements have the potential to explain the effect of CEO duality on firm performance, and thus future studies may consider these variables as mediators or moderators.

Author Contributions: R.M. conceptualization, methodology, formal analysis, resources, writing-original draft preparation, writing-review and editing, J.A. supervision and study design, writing abstract and discussion, review and editing and approving the edited manuscript. J.A., I.H. and D.H. contributed in literature and supervised this study. All authors have read and agreed to the published version of the manuscript.

Funding: The Heilongjiang Natural Science Foundation (HGQQ2440501511) supported this research.

Conflicts of Interest: All authors approved this manuscript. No author has financial or other contractual agreements that might cause conflicts of interest.

\section{References}

1. Oak, S.; Iyengar, R.J. Investigating the differences in corporate governance between hospitality and nonhospitality firms. In Advances in Hospitality and Leisure; Emerald Group Publishing Limited: Bingley, UK, 2009; pp. 125-140.

2. Finkelstein, S.; Cannella SF, B.; Hambrick, D.C.; Cannella, A.A. Strategic Leadership: Theory and Research on Executives, Top Management Teams, and Boards; Oxford University Press: Oxford, MS, USA, 2009.

3. Wang, G.; DeGhetto, K.; Ellen, B.P.; Lamont, B.T. Board Antecedents of CEO Duality and the Moderating Role of Country-level Managerial Discretion: A Meta-analytic Investigation. J. Manag. Stud. 2019, 56, 172-202. [CrossRef]

4. Faleye, O. Does one hat fit all? The case of corporate leadership structure. J. Manag. Gov. 2007, 11, $239-259$. [CrossRef]

5. Aktas, N.; Andreou, P.; Karasamani, I.; Philip, D. CEO Duality, Agency Costs, and Internal Capital Allocation Efficiency. Br. J. Manag. 2019, 30, 473-493. [CrossRef]

6. Iyengar, R.J.; Zampelli, E.M. Self-selection, endogeneity, and the relationship between CEO duality and firm performance. Strat. Manag. J. 2009, 30, 1092-1112. [CrossRef]

7. Guillet, B.D.; Seo, K.; Kucukusta, D.; Lee, S. CEO duality and firm performance in the U.S. restaurant industry: Moderating role of restaurant type. Int. J. Hosp. Manag. 2013, 33, 339-346. [CrossRef] 
8. Core, J.E.; Holthausen, R.W.; Larcker, D.F. Corporate governance, chief executive officer compensation, and firm performance. J. Financ. Econ. 1999, 51, 371-406. [CrossRef]

9. Fama, E.F.; Jensen, M.C. Separation of Ownership and Control. J. Law Econ. 1983, 26, 301-325. [CrossRef]

10. Jensen, M.C.; Meckling, W.H. Theory of the firm: Managerial behavior, agency costs and ownership structure. J. Financ. Econ. 1976, 3, 305-360. [CrossRef]

11. Finkelstein, S.; D'Aveni, R.A. CEO Duality as a Double-Edged Sword: How Boards of Directors Balance Entrenchment Avoidance and Unity of Command. Acad. Manag. J. 1994, 37, 1079-1108.

12. Dahya, J.; Lonie, A.A.; Power, D. The case for separating the roles of chairman and CEO: An analysis of stock market and accounting data. Corp. Gov. Int. Rev. 1996, 4, 71-77. [CrossRef]

13. Yang, T.; Zhao, S.; Yang, T.; Zhao, S. CEO duality and firm performance: Evidence from an exogenous shock to the competitive environment. J. Bank. Financ. 2014, 49, 534-552. [CrossRef]

14. Tang, J. CEO duality and firm performance: The moderating roles of other executives and blockholding outside directors. Eur. Manag. J. 2017, 35, 362-372. [CrossRef]

15. Frank, M.; Goyal, V. Testing the pecking order theory of capital structure. J. Financ. Econ. 2003, 67, $217-248$. [CrossRef]

16. Naseem, M.A.; Lin, J.; Rehman, R.U.; Ahmed, M.I.; Ali, R. Does capital structure mediate the link between CEO characteristics and firm performance? Manag. Decis. 2020, 58, 164-181. [CrossRef]

17. Giroud, X.; Mueller, H.M. Corporate Governance, Product Market Competition, and Equity Prices. J. Financ. 2011, 66, 563-600. [CrossRef]

18. Liu, Q. Corporate Governance in China: Current Practices, Economic Effects and Institutional Determinants. Cesifo Econ. Stud. 2006, 52, 415-453. [CrossRef]

19. Walsh, J.P.; Seward, J.K. On the efficiency of internal and external corporate control mechanisms. Acad. Manag. Rev. 1990, 15, 421-458. [CrossRef]

20. Duru, A.; Iyengar, R.J.; Zampelli, E.M. The dynamic relationship between CEO duality and firm performance: The moderating role of board independence. J. Bus. Res. 2016, 69, 4269-4277. [CrossRef]

21. Lew, Y.K.; Yu, J.; Park, J.-Y. The impacts of independent director and CEO duality on performance in the Chinese post-institutional-transition era. Can. J. Adm. Sci. Rev. Can. Sci. l'Administration 2018, 35, 620-634. [CrossRef]

22. Saeed, A.; Athreye, S. Internal capital markets and outward foreign investment from India and China. In International Business and Institutions after the Financial Crisis; Springer: Berlin/Heidelberg, Germany, 2014; pp. 93-108.

23. Peng, M.W.; Li, Y.; Xie, E.; Su, Z. CEO duality, organizational slack, and firm performance in China. Asia Pac. J. Manag. 2010, 27, 611-624. [CrossRef]

24. Li, H.; Chen, P. Board gender diversity and firm performance: The moderating role of firm size. Bus. Ethic- A Eur. Rev. 2018, 27, 294-308. [CrossRef]

25. Conyon, M.J.;He, L. Executive compensation and corporate governance in China. J. Corp. Financ. 2011, 17, 1158-1175. [CrossRef]

26. Su, Z.; Peng, J.; Shen, H.; Xiao, T. Technological Capability, Marketing Capability, and Firm Performance in Turbulent Conditions. Manag. Organ. Rev. 2013, 9, 115-137. [CrossRef]

27. Krause, R.; Semadeni, M.; Cannella, A.A., Jr. CEO duality: A review and research agenda. J. Manag. 2014, 40, 256-286. [CrossRef]

28. Fan, J.P.; Wong, T.; Zhang, T. Politically connected CEOs, corporate governance, and Post-IPO performance of China's newly partially privatized firms. J. Financ. Econ. 2007, 84, 330-357. [CrossRef]

29. Faleye, O. Classified boards, firm value, and managerial entrenchment. J. Financ. Econ. 2007, 83, 501-529. [CrossRef]

30. Mallette, P.; Fowler, K.L. Effects of Board Composition and Stock Ownership on the Adoption of "Poison Pills". Acad. Manag. J. 1992, 35, 1010-1035.

31. Krause, R. Being the CEO's boss: An examination of board chair orientations. Strat. Manag. J. 2017, 38, 697-713. [CrossRef]

32. Nahar Abdullah, S. Board composition, CEO duality and performance among Malaysian listed companies. Corp. Gov. Int. J. Bus. Soc. 2004, 4, 47-61. [CrossRef]

33. Mutlu, C.C.; Van Essen, M.; Peng, M.W.; Saleh, S.F.; Duran, P. Corporate Governance in China: A Meta-Analysis. J. Manag. Stud. 2018, 55, 943-979. [CrossRef] 
34. Pollock, T.G.; Fischer, H.M.; Wade, J.B. The role of power and politics in the repricing of executive options. Acad. Manag. J. 2002, 45, 1172-1182.

35. Boyd, B.K. CEO duality and firm performance: A contingency model. Strateg. Manag. J. 1995, 16, $301-312$. [CrossRef]

36. Beasley, M.S. An empirical analysis of the relation between the board of director composition and financial statement fraud. Account. Rev. 1996, 443-465.

37. Eisenhardt, K.M. Making Fast Strategic Decisions In High-Velocity Environments. Acad. Manag. J. 1989, 32, 543-576.

38. Chahine, S.; Tohmé, N.S. Is CEO Duality Always Negative? An Exploration of CEO Duality and Ownership Structure in the Arab IPO Context. Corp. Governance Int. Rev. 2009, 17, 123-141. [CrossRef]

39. Ramdani, D.; Van Witteloostuijn, A. The Impact of Board Independence and CEO Duality on Firm Performance: A Quantile Regression Analysis for Indonesia, Malaysia, South Korea and Thailand. Br. J. Manag. 2010, 21, 607-627. [CrossRef]

40. Donaldson, L.; Davis, J.H. Stewardship Theory or Agency Theory: CEO Governance and Shareholder Returns. Aust. J. Manag. 1991, 16, 49-64. [CrossRef]

41. Davis, J.H.; Schoorman, F.D.; Donaldson, L. Toward a stewardship theory of management. Acad. Manag. Rev. 1997, 22, 20-47. [CrossRef]

42. Brickley, J.A.; Coles, J.L.; Jarrell, G. Leadership structure: Separating the CEO and Chairman of the Board. J. Corp. Financ. 1997, 3, 189-220. [CrossRef]

43. Desai, A.; Kroll, M.; Wright, P. CEO duality, board monitoring, and acquisition performance: A test of competing theories. J. Bus. Strateg. 2003, 20, 137.

44. Stoeberl, P.; Sherony, B. Board efficiency and effectiveness. In Handbook for Corporate Directors; McGraw-Hill: New York, NY, USA, 1985; pp. 12.1-12.10.

45. Larcker, D.; Tayan, B. Corporate Governance Matters: A Closer Look at Organizational Choices and Their Consequences; Pearson Education: London, UK, 2015.

46. Jensen, M.C.; Heckling, W.H. Specific and general knowledge, and organizational structure. J. Appl. Corp. Financ. 1995, 8, 4-18. [CrossRef]

47. Bhagat, S.; Black, B.S. The Non-Correlation Between Board Independence and Long-Term Firm Performance. SSRN Electron. J. 1998, 27, 231. [CrossRef]

48. Dalton, D.R.; Daily, C.M.; Ellstrand, A.E.; Johnson, J.L. Meta-analytic reviews of board composition, leadership structure, and financial performance. Strateg. Manag. J. 1998, 19, 269-290. [CrossRef]

49. Gohar, R.; Batool, A. Effect of Corporate Governance on Performance of Microfinance Institutions: A Case from Pakistan. Emerg. Mark. Financ. Trade 2015, 51, S94-S106. [CrossRef]

50. Singh, S.; Tabassum, N.; Darwish, T.K.; Batsakis, G. Corporate Governance and Tobin'sQas a Measure of Organizational Performance. Br. J. Manag. 2018, 29, 171-190. [CrossRef]

51. Elsayed, K. Does CEO Duality Really Affect Corporate Performance? Corp. Gov. Int. Rev. 2007, 15, 1203-1214. [CrossRef]

52. Jiraporn, P.; Chintrakarn, P.; Liu, Y. Capital structure, CEO dominance, and corporate performance. J. Financ. Serv. Res. 2012, 42, 139-158. [CrossRef]

53. Stulz, R. Managerial control of voting rights. J. Financ. Econ. 1988, 20, 25-54. [CrossRef]

54. Fosberg, R.H. Agency problems and debt financing: Leadership structure effects. Corp. Gov. Int. J. Bus. Soc. 2004, 4, 31-38. [CrossRef]

55. Abor, J. Debt policy and performance of SMEs. J. Risk Financ. 2007, 8, 364-379. [CrossRef]

56. Bokpin, G.A.; Arko, A.C. Ownership structure, corporate governance and capital structure decisions of firms. Stud. Econ. Financ. 2009, 26, 246-256. [CrossRef]

57. Margaritis, D.; Psillaki, M. Capital structure, equity ownership and firm performance. J. Bank. Financ. 2010, 34, 621-632. [CrossRef]

58. Chintrakarn, P.; Jiraporn, P.; Singh, M. Powerful CEOs and capital structure decisions: Evidence from the CEO pay slice (CPS). Appl. Econ. Lett. 2014, 21, 564-568. [CrossRef]

59. Hitt, M.A.; Hoskisson, R.E.; Johnson, R.A.; Moesel, D.D. The market for corporate control and firm innovation. Acad. Manag. J. 1996, 39, 1084-1119.

60. Franko, L.G. Global corporate competition: Who's winning, who's losing, and the R\&D factor as one reason why. Strat. Manag. J. 1989, 10, 449-474. 
61. Ko, H.-C.A.; Tong, Y.; Zhang, F.; Zheng, G. Corporate governance, product market competition and managerial incentives: Evidence from four Pacific Basin countries. Pac.-Basin Financ. J. 2016, 40, 491-502. [CrossRef]

62. Giroud, X.; Mueller, H.M. Does corporate governance matter in competitive industries? J. Financ. Econ. 2010, 95, 312-331. [CrossRef]

63. Tian, G.Y.; Twite, G. Corporate governance, external market discipline and firm productivity. J. Corp. Financ. 2011, 17, 403-417. [CrossRef]

64. Karunananthan, C. Industry product market competition and managerial incentives. J. Account. Econ. 2007, 43, 275-297.

65. Bloom, N.; Sadun, R.; van Reenen, J. Does product market competition lead firms to decentralize? Am. Econ. Rev. 2010, 100, 434-438. [CrossRef]

66. Schmidt, K.M. Managerial Incentives and Product Market Competition. Rev. Econ. Stud. 1997, 64, $191-213$. [CrossRef]

67. Dhaliwal, D.; Huang, S.; Khurana, I.K.; Pereira, R. Product market competition and conditional conservatism. Rev. Account. Stud. 2014, 19, 1309-1345. [CrossRef]

68. Gunasekarage, A.; Luong, H.; Truong, T.T. Growth and market share matrix, CEO power, and firm performance. Pac. Basin Financ. J. 2020, 59, 101257. [CrossRef]

69. Raith, M. Competition, Risk, and Managerial Incentives. Am. Econ. Rev. 2003, 93, 1425-1436. [CrossRef]

70. Grosfeld, I.; Tressel, T. Competition and ownership structure: Substitutes or complements? Evidence from the Warsaw Stock Exchange1. Econ. Transit. 2002, 10, 525-551. [CrossRef]

71. Pant, M.; Pattanayak, M. Corporate Governance, Competition and Firm Performance. J. Emerg. Mark. Financ. 2010, 9, 347-381. [CrossRef]

72. Sheikh, S. The impact of market competition on the relation between CEO power and firm innovation. J. Multinatl. Financ. Manag. 2018, 44, 36-50. [CrossRef]

73. Javeed, S.A.; Latief, R.; Lefen, L. An analysis of relationship between environmental regulations and firm performance with moderating effects of product market competition: Empirical evidence from Pakistan. J. Clean. Prod. 2020, 254, 120197. [CrossRef]

74. Li, M.; Lu, Y.; Phillips, G.M. CEOs and the Product Market: When Are Powerful CEOs Beneficial? J. Financ. Quant. Anal. 2018, 54, 2295-2326. [CrossRef]

75. Ammann, M.; Oesch, D.; Schmid, M.M. Product Market Competition, Corporate Governance, and Firm Value: Evidence from the EU Area. Eur. Financ. Manag. 2013, 19, 452-469. [CrossRef]

76. Baron, R.M.; Kenny, D.A. The moderator-mediator variable distinction in social psychological research: Conceptual, strategic, and statistical considerations. J. Personal. Soc. Psychol. 1986, 51, 1173. [CrossRef]

77. Tien, C.; Chen, C.-N.; Chuang, C.-M. A study of CEO power, pay structure, and firm performance. J. Manag. Organ. 2013, 19, 424-453. [CrossRef]

78. Tam, O.K.; Tan, M.G.-S. Ownership, Governance and Firm Performance in Malaysia. Corp. Gov. Int. Rev. 2007, 15, 208-222. [CrossRef]

79. Berg, S.V.; Smith, S.K. CEO and board chairman: A quantitative study of dual vs. unitary board leadership. Dir. Boards 1978, 3, 34-39.

80. Chen, C.-W.; Lin, J.S.B.; Yi, B. CEO duality and firm performance-An endogenous issue. Corp. Ownersh. Control 2008, 6, 58-65. [CrossRef]

81. Li, Y.; Gong, M.; Zhang, X.-Y.; Koh, L. The impact of environmental, social, and governance disclosure on firm value: The role of CEO power. Br. Account. Rev. 2018, 50, 60-75. [CrossRef]

82. Dang, C.; Li, Z.; Yang, C. Measuring firm size in empirical corporate finance. J. Bank. Finance 2018, 86, 159-176. [CrossRef]

83. Abbas, J.; Mahmood, S.; Ali, H.; Ali Raza, M.; Ali, G.; Aman, J.; Bano, S.; Nurunnabi, M. The Effects of Corporate Social Responsibility Practices and Environmental Factors through a Moderating Role of Social Media Marketing on Sustainable Performance of Business Firms. Sustainability 2019, 11, 3434. [CrossRef]

84. Abbas, J.; Raza, S.; Nurunnabi, M.; Minai, M.S.; Bano, S. The Impact of Entrepreneurial Business Networks on Firms' Performance Through a Mediating Role of Dynamic Capabilities. Sustainability 2019, 11, 3006. [CrossRef] 
85. Azhar, A.; Abbas, J.; Wenhong, Z.; Akhtar, T.; Aqeel, M. Linking infidelity stress, anxiety and depression: Evidence from Pakistan married couples and divorced individuals. Int. J. Hum. Rights Healthc. 2018, 11, 214-228. [CrossRef]

86. Fosu, S. Capital structure, product market competition and firm performance: Evidence from South Africa. Q. Rev. Econ. Financ. 2013, 53, 140-151. [CrossRef]

87. Zou, H.L.; Zeng, S.X.; Lin, H.; Xie, X.M. Top executives' compensation, industrial competition, and corporate environmental performance. Manag. Decis. 2015, 53, 2036-2059. [CrossRef]

88. Michaelides, P.G.; Tsionas, E.G.; Konstantakis, K.N.; Xidonas, P. The impact of market competition on CEO salary in the US energy sector1. Energy Policy 2019, 132, 32-37. [CrossRef]

89. Jain, B.A.; Li, J.; Shao, Y. Governance, product market competition and cash management in IPO firms. J. Bank. Financ. 2013, 37, 2052-2068. [CrossRef]

90. Sardana, D.; Gupta, N.; Kumar, V.; Terziovski, M. CSR ‘sustainability' practices and firm performance in an emerging economy. J. Clean. Prod. 2020, 258, 120766. [CrossRef]

91. Song, H.J.; Yoon, Y.N.; Kang, K.H. The relationship between board diversity and firm performance in the lodging industry: The moderating role of internationalization. Int. J. Hosp. Manag. 2020, 86, 102461. [CrossRef]

92. Nekhili, M.; Chakroun, H.; Chtioui, T. Women's Leadership and Firm Performance: Family Versus Nonfamily Firms. J. Bus. Ethic 2018, 153, 291-316. [CrossRef]

93. Hermalin, B.E.; Weisbach, M.S. Boards of Directors as an Endogenously Determined Institution: A Survey of the Economic Literature; National Bureau of Economic Research: Cambridge, MA, USA, 2001.

94. Kang, E.; Zardkoohi, A. Board Leadership Structure and Firm Performance. Corp. Gov. Int. Rev. 2005, 13, 785-799. [CrossRef]

95. Adams, R.; Hermalin, B.E.; Weisbach, M.S. The Role of Boards of Directors in Corporate Governance: A Conceptual Framework and Survey. J. Econ. Lit. 2010, 48, 58-107. [CrossRef]

96. Li, F. Endogeneity in CEO power: A survey and experiment. Invest. Anal. J. 2016, 45, 149-162. [CrossRef]

97. Arellano, M.; Bond, S. Some Tests of Specification for Panel Data: Monte Carlo Evidence and an Application to Employment Equations. Rev. Econ. Stud. 1991, 58, 277-297. [CrossRef]

98. Hair, J.F.; Black, W.C.; Babin, B.J.; Anderson, R.E.; Tatham, R.L. Multivariate Data Analysis; Pearson Prentice Hall: Upper Saddle River, NJ, USA, 2006; Volume 6.

99. Sheikh, S. CEO power, product market competition and firm value. Res. Int. Bus. Financ. 2018, 46, 373-386. [CrossRef]

100. Pham, N.; Oh, K.; Pech, R. Mergers and acquisitions: CEO duality, operating performance and stock returns in Vietnam. Pac. Basin Financ. J. 2015, 35, 298-316. [CrossRef]

101. Abbas, J.; Zhang, Q.; Hussain, I.; Akram, S.; Afaq, A.; Shad, M.A. Sustainable Innovation in Small Medium Enterprises: The Impact of Knowledge Management on Organizational Innovation through a Mediation Analysis by Using SEM Approach. Sustainability 2020, 12, 2407. [CrossRef]

102. Abbas, J.; Zhang, Q.; Hussain, I.; Akram, S.; Afaq, A.; Shad, M.A. The Impact of Knowledge Sharing and Innovation on Sustainable Performance in Islamic Banks: A Mediation Analysis through a SEM Approach. Sustainability 2019, 11, 4049. [CrossRef]

103. Abbas, J.; Aman, J.; Nurunnabi, M.; Bano, S. The moderating role of social support for marital adjustment, depression, anxiety, and stress: Evidence from Pakistani working and nonworking women. J. Affect. Disord. 2019, 244, 231-238. [CrossRef]

104. Chintrakarn, P.; Chatjuthamard, P.; Tong, S.; Jiraporn, P. How do powerful CEOs view dividends and stock repurchases? Evidence from the CEO pay slice (CPS). Int. Rev. Econ. Financ. 2018, 58, 49-64. [CrossRef]

105. Abbas, J.; Aqeel, M.; Jaffar, A.; Nurunnabi, M.; Bano, S. Tinnitus perception mediates the relationship between physiological and psychological problems among patients. J. Exp. Psychopathol. 2019, 10, 2043808719858559. [CrossRef]

106. Abbas, J.; Aqeel, M.; Wenhong, Z.; Aman, J.; Zahra, F. The moderating role of gender inequality and age among emotional intelligence, homesickness and development of mood swings in universitystudents. Int. J. Hum. Rights Healthc. 2018, 11, 356-367. [CrossRef]

(C) 2020 by the authors. Licensee MDPI, Basel, Switzerland. This article is an open access article distributed under the terms and conditions of the Creative Commons Attribution (CC BY) license (http://creativecommons.org/licenses/by/4.0/). 